\title{
Macroeconomic Uncertainty and Cash Holdings of Top 50 Listed Firms in Vietnam Stock Exchange
}

\author{
Van Dung $\mathrm{Ha}^{*}$
}

\author{
Banking University Ho Chi Minh City, Vietnam
}

\begin{abstract}
This study investigates the impact of macroeconomic uncertainty on cash holdings of top 50 listed firms in Vietnam Stock Exchange. The average of natural logarithm of inflation rate, change in exchange rate, deficit to GNP, and external debt to GNP ratio is used for macroeconomic uncertainty while the ratio of cash and cash equivalent to total assets measures firm cash holdings. Using a dataset of 300 observations from top 50 listed firms in both Ho Chi Minh City Stock Exchange and Hanoi stock Exchange from 2013-2018, the paper employs the basic quantitative methods of Pooled Ordinary Least Squared, Fxed effects model, and Random effects model for analysis. The results indicate that higher macroeconomic uncertainty may lead to higher cash holdings of listed firms in Vietnam Stock Exchange. Some other determinants of firm cash holdings can be named as firm size, the ratio of market and booked value of firm, cash flow, net working capital, firm investment, leverage, and firm dividend. One macroeconomic indicator (the growth rate of money supply) is also found to have positive impacts of cash holdings of firms in Vietnam Stock Exchange.
\end{abstract}

Keywords: Cash holdings, Macroeconomic uncertainty, Firms, Dividend, Money supply.

\section{MOTIVATION AND NOVELTY}

Vietnam is one of countries which are affected by the recession during 2008-2011. In addition to the unfavorable external economic environment, internal factors as high inflation, increasing public debt, high interest rate, or unstable exchange rate, etc. result more obstacles to the Vietnamese economy. To solve the economic problems, policy makers issue short-run decisions, which cause negative impacts on domestic enterprises such as lack of credit, higher capital cost and opportunity cost, etc. Over the past decade, Vietnamese economy has been recovered, but unpredictable. Being suffered adverse economic conditions, enterprises become more careful in their business. They pay more attention on their capital, especially on their cash flow. To ensure the business, enterprises now regard cash holding one of the most important decisions. Cash holding can reflect the enterprise plan as well as the financial strategy. Moreover, internal management of the enterprises and external macroeconomics could be reflected via firm's cash holding. Firm cash holdings are found to be determined by macroeconomic indicators as well as firm size, the ratio of market and booked value of firm, cash flow, net working capital, firm investment, leverage, and firm dividend

\section{METHODOLOGY AND METHODS}

Quantitative method is used for the research. Pooled Ordinary Least Squared, Fixed effects model, and Random effects model for panel data is employed.

*Address correspondence to this author at the Banking University Ho Chi Minh City, Vietnam; E-mail: dunghv@buh.edu.vn

JEL classification: D22, M21, 012

\section{DATA AND EMPIRICAL ANALYSIS}

The data are collected from top 50 enterprises in both Ho Chi Minh City Stock Exchange (HOSE) and Hanoi stock Exchange (HNX) from 2013-2018. Top 50 enterprises have been named by Forbes Vietnam. The list of 50-best-listed enterprises has been issued every year from 2013. The year 2018 is considered the base year for identifying firms and collecting firm data. Macroeconomic data is extracted from the World Development Indicators 2019.

The results from FEM model indicate that macroeconomic uncertainty (MII and M2) has significant impacts on cash holdings of firms. Other control variables such as SIZE, MB, CF, NWC, CAPEX, LEV, and DIV affect cash holdings of firms at $1 \%, 5 \%$, and $10 \%$ level of significance.

MII has significant impacts on cash holdings of top 50 listed firms in Vietnam stock market. This confirms the findings of Demir and Ersan (2017), and Phan et al. (2017). The result indicates that higher macroeconomic uncertainty will lead to higher cash holdings in firms. In 2008, when the economy fell into the recession, firms had to increase reserve as well as be more careful in investment to ensure the cash flow. In recent years, the Vietnamese economy has been recovered while inflation and interest rate are under control. As a result of stable economy, firms has reduced reserve for precautionary motive and utilized capital resource for firm's operation. This confirms the hypothesis that higher macroeconomic uncertainty will result higher level of cash holdings of firms. The same effect happens to money supply (M2). M2 has significantly positive impacts on cash holdings (Yang et al., 2017).

(c) 2020 Lifescience Global 
Firm size (SIZE) has negative impacts on cash holdings of listed firms in Vietnam stock market. This direction of significant impacts is similar to those of Ozkan and Ozkan (2004), and Phan et al. (2017). The result shows the diseconomies to scale in cash holdings and confirms the hypothesis that bigger firms hold less money. It can be explained that most of transactions in bigger firms via banking system and thus these firms hold less cash.

Market-booked value of firms has significant and positive impacts on cash holdings of top 50 listed firms in Vietnam Stock Market. This result is supported by Ozkan and Ozkan (2004), and Ferreira and Vilela (2004). Higher rate between market value and booked value of firms would result higher level of firm cash holdings. Firms with higher rate of MB may have higher opportunity to promote their market or products, which need internal liquidity to support the chance. Higher investment opportunity would in turn increase market value of firms, and thus confirms the research hypothesis (Ferreira and Vilela, 2004; Phan et al., 2017). Cash flow, Leverage and firm investment have positive effects on firm cash holdings and this result is in accordance to those of Anderson (1999), Ferreira and Vilela, (2004), Ozkan and Ozkan (2004), Drobetz and Grüninger (2007), Ogundipe et al. (2012), and Phan et al. (2017).

Net Working Capital and dividend significantly affect firm cash holdings. The negative sign of NWC coefficients imply that whenever NWC increases, cash in firm will reduce. This also shows that firms with low opportunity cost of liquidity will hold less cash (Phan et al., 2017). There is difference between firms with dividend in cash and firms with no dividend. Dividend in cash will reduce the amount of cash in firms or after paying dividend in cash, firms will have lower level of cash.

\section{POLICY CONSIDERATION}

The empirical results reveal some implications for policy makers. Firstly, firms hold less cash in a stable economic environment. This means that when the government want to minimize the cash transaction as well as cash holdings in firms, it is necessary to hold the macroeconomic stable. Like other developing economies, there is a large amount of cash in the economy while the usage of electronic money is still limited. Besides the regulations, stability of macroeconomic conditions such as economic growth, inflation, deficit, and external debt are important factor in reducing cash holdings of firms. In addition, the monetary policy should be carefully used when considering the amount of cash holdings in firms. Increasing money supply would also directly affect cash holdings and indirectly via inflation. Secondly, policy on cash holdings of firms should pay attention to some determinants such as firm size, cash flow, net working capital, investment, leverage, as well as firm dividend policy in order to reach the targeted level of firm cash holdings. Changes of these determinants can affect cash holdings so the policy must be sufficiently adjusted.

\section{INTRODUCTION}

The global economic crisis from 2008 affected most of the economies in the world. Vietnam is one of the most affected one. In addition to the unfavorable external economic environment, internal factors as high inflation, increasing public debt, high interest rate, or unstable exchange rate, etc. result more obstacles to the Vietnamese economy. To solve the economic problems, policy makers issue short-run decisions, which cause negative impacts on domestic enterprises such as lack of credit, higher capital cost and opportunity cost, etc. Over the past decade, Vietnamese economy has been recovered, but unpredictable. Being suffered adverse economic conditions, enterprises become more careful in their business. They pay more attention on their capital, especially on their cash flow. To ensure the business, enterprises now regard cash holding one of the most important decisions. Cash holding can reflect the enterprise plan as well as the financial strategy (Yepifanova, 2019; Zakaria et al., 2019). Moreover, internal management of the enterprises and external macroeconomics could be reflected via firm's cash holding.

In the recent years, Vietnam has highly integrated into the world economy, which results high competition pressure on domestic firms. Cash holdings become more important as firms want to ensure long-term growth and development. Cash serves not only liquidity but also investment and firm operation. However, cash holdings generate opportunity cost for firms. So, effective level of cash holdings is crucial issue in maximizing profit but minimizing costs. External environment may affect cash holdings in such way that stable economy may lead to lower level of cash holdings as stated in some researches (Chen et al., 2014; Yang et al., 2017). The research on firm cash holdings in Vietnam is mostly neglect the role of 
macroeconomic factors. This research may contribute an empirical view on the literature of cash holdings in Vietnam.

\section{LITERATURE REVIEW}

The researches on the impacts of macroeconomic factors on cash holdings have been done across economies.

A research of Pinkowitz et al. (2003) used firm-level data in 35 economies from 1988 - 1999. In this study, the liquid assets were found to be more in higher risk economies. The uncertainty of the macroeconomic conditions led the firm to a stable cash policy, which demands more cash holdings. In poor protection of investor rights, the transaction and precautionary motive of money theories was still hold. In such economies, firm managers had to face with the tradeoff between risk and cash holdings and in most cases, cash holdings were referred.

Baum et al. (2006) investigated the impacts of macroeconomic conditions on liquid assets of nonfinancial firms. The firm policy would be affected by macroeconomic uncertainty. The firm managers could not accurately estimate the information to make the right cash management. The misallocation of capital resource may harm the firm performance. By contrast, if the macroeconomic conditions are stable, it would be the favorable environment for firms to adjust their liquid assets. The efficient allocation of assets would result higher capital efficiency.

According to Bates et al. (2009), the increase of average cash ratio was largely affected by the precautionary motive of holding cash. During the period from 1980 to 2006, the average cash-to-assets ratio had doubled in US industrial enterprises. Cash holdings can secure firms away from risk of debt obligations. At the end of each year, average firm can use its cash to pay back all its debts. It means that at that time the average firm holds no leverage, or firm has no risk of debts. The increase in cash holding ratio over this period is the result of reaction to economic conditions.

Chen et al. (2014) examined the impacts of government quality on firm's cash holdings in China. The government expropriation with minimized argument of financial constraint is the core of the research. They found that when the quality of the local government is high, less money would be held at the firms. High government quality would increase investment which reduces cash holdings in private firms. Local government can also increase firm's probability in accessing bank credits as well as other financings. Interactions between local government and firms were found in this research.

In the research of Demir and Ersan (2017), the impact of policy uncertainty on cash holdings of firms in BRIC economies was examined. Using firm data from 2006 to 2015, the authors found that under uncertainty of macroeconomic policy, firms would hold more cash. Classifying controlled variables into groups such as industry, year, and country specific, the paper found the same results of the impact of macroeconomic uncertainty under the fixed effects of controlled variables. In addition, global economic uncertainty also had significantly positive effects on cash holdings of firms.

In summary, most of previous studies found that macroeconomic conditions had impacts on cash management of firms. When there is uncertainty of macroeconomic environment, firms tend to hold more money to cover their capital demand. The economic fluctuation in developing economies such as Vietnam is often higher. The uncertainty of macroeconomic conditions, therefore, may have strong impact on the decision to hold cash in each firm. This paper is to investigate the impacts of macroeconomic uncertainty on cash holdings of non-financial firms in Vietnam stock market.

\section{METHODOLOGY}

The study employs quantitative method to test the impacts of macroeconomic uncertainty on cash holding of non-financial firms in Vietnam. The data are collected from top 50 enterprises in both Ho Chi Minh City Stock Exchange (HOSE) and Hanoi stock Exchange (HNX) from 2013-2018. Top 50 enterprises have been named by Forbes Vietnam. The list of 50 best-listed enterprises has been issued every year from 2013. The year 2018 is considered the base year for identifying firms and collecting firm data. Macroeconomic data is extracted from the World Development Indicators 2019.

Regarding to the previous studies such as those of Ismihan et al. (2002) and Chen et al. (2014), this paper forms the model as following:

$\mathrm{CASH}=\beta_{0}+\beta_{1} \mathrm{MII}_{\mathrm{i}, \mathrm{t}-1}+\beta_{2} \mathrm{M}_{\mathrm{i}, \mathrm{t}-1}+\beta_{3}$ Size $_{\mathrm{i}, \mathrm{t}}+\beta_{4} \mathrm{MB}_{\mathrm{i}, \mathrm{t}}+$ $\beta_{5} \mathrm{CF}_{\mathrm{i}, \mathrm{t}}+\beta_{6} \mathrm{NWC}_{\mathrm{i}, \mathrm{t}}+\beta_{7}$ Capex $_{\mathrm{i}, \mathrm{t}}+\beta_{8}$ Leverage $_{\mathrm{i}, \mathrm{t}}+$ $\beta_{9}$ Dividend $_{i, t}+e_{i, t}$ 


\section{Dependent Variable}

$\mathrm{CASH}$ is firm cash holdings and measured by the total firm cash and cash equivalent to total assets (Kim et al., 1998; Ozkan and Ozkan, 2004; Bates et al., 2009).

\section{Independent Variables}

Macroeconomic uncertainty indicator (MII) is used as proxy of macroeconomic uncertainty. MII is measured in natural logarithm of the average of natural logarithm of four macroeconomic indicators: inflation rate, change in exchange rate, deficit to GNP and external debt to GNP ratio (Ismihan et al., 2002). Macroeconomic uncertainty was found to have positive impacts on cash holdings in BRIC (Demir and Ersan, 2017). So, the first hypothesis will be:

Hypothesis 1: MII has a positive impact on cash holdings.

The growth rate of money supply (M2) is measured by the percentage change in money supply (M2) (M2 = (money supply 2 - money supply1)/money supply1). In the study of Yang et al. (2017), monetary policy has positive impacts on firm cash holdings. The reduction of money supply will result light decrease of cash holdings. And, the second hypothesis is as following:

Hypothesis 2: The growth rate of money supply will positively affect firm cash holdings.

Firm size (SIZE) is measured by natural logarithm of firm total assets (SIZE $=\operatorname{Ln}($ total assets)). Most studies found that bigger firms hold less money since these firms have higher access possibility to external capital (Anderson, 1999; Ferreira and Vilela, 2004; Ogundipe et al., 2012). The third hypothesis will be:

Hypothesis 3: Firm size negatively affects cash holdings.

Market-booked value of firm (MB) is the rate between market value and booked value of firm shares (MB = market/booked value of firm shares). Ozkan and Ozkan (2004), or Ferreira and Vilela (2004) indicated that firms with higher MB would have a tendency to keep more money to cover higher cost. In addition, firms having higher opportunity in market development would face higher representative cost, and thus these firms need more cash. According to Ferreira and Vilela (2004), and Phan et al. (2017), bigger opportunity would generate higher market value of firm. However, investment opportunity is not counted in accounting balance sheets, the MB would be used for the investment opportunity. The forth hypothesis will be:

Hypothesis 4: Market-booked value of firm positively affects cash holdings.

Cash flow (CF) is calculated by the rate between the sum of profit after tax and depreciation and the subtraction result of cash and cash equivalents from total assets (Ferreira and Vilela, 2004; Ogundipe et al., 2012).

$\mathrm{CF}=\frac{\text { Profit fater tax }+ \text { depreciation }}{\text { Total assets }- \text { cash and cash equivalents }}$

Previous studies showed that larger CF firms refer to hold cash (Anderson, 1999; Ozkan and Ozkan, 2004; Ogundipe et al., 2012). The next hypothesis is as following:

Hypothesis 5: Firm cash flow will positively affect cash holdings.

Net Working Capital (NWC) is the ratio between current assets and current liabilities (NWC= current assets/current liabilities). NWC in this research is measured by natural logarithm of NWC. NWC ensures firm properly operates as well as cover short-term debts and operating costs (Afza and Adnan, 2007; Gill and Shah, 2012). So, NWC can be representative of high liquid assets (Phan et al., 2017). Larger NWC may reduce the cash reserve. So, the sixth hypothesis will be:

Hypothesis 6: Net working capital would reduce the cash holdings.

Firm investment (CAPEX) is measured by the rate of total investment to total assets (CAPEX $=$ total investment/total assets). Ozkan and Ozkan (2004), and Ferreira and Vilela (2004) showed that firms with higher investment level refer to hold more cash in order not to miss the investment opportunity. The seventh hypothesis would be:

Hypothesis 7: Firm investment has positive impacts on cash holdings.

Leverage (LEV) is measured by firm total debt to total assets (LEV = total debt/total assets). The negative impact of leverage on cash holdings has been supported by Anderson (1999); Ozkan and Ozkan (2004); Ferreira and Vilela (2004); Drobetz and 
Grüninger (2007); and Bahmani-Oskooee et al. (2013). However, recent studies found positive effect of leverage on cash holdings (Hemmati et al., 2013; Ogundipe et al., 2012; Islam, 2012; Gill and Shah, 2012; and Phan et al., 2017). The paper proposes the hypothesis:

Hypothesis 8: Firm leverage positively affects cash holdings.

Dividend (DIV) can be used for cash management (DIV $=1$ if firm pays dividend, 0 otherwise). Firms pay no dividend in the research year tend to hold more cash (Gill and Shah, 2012; Phan et al., 2017). So, the proposed hypothesis would be:

Hypothesis 9: Firm paying no dividend would hold more cash.
To investigate the impacts of macroeconomic uncertainty as well as other determinants of firm cash holdings, the paper employs Pooled OLS (POLS) as well as fixed effects model (FEM) and random effects model (REM), which are suitable for panel data in this case. Post estimation tests such as test of multicollinearity, heteroskedasticity, and serial correlation will be used for the reliable results. Hausman test will also be used to model selection for analysis.

\section{RESULTS}

A balanced panel data set of total 300 observations (50 firms from 2013-2018) has been collected and employed in the research.

Table 1: Descriptive Statistics

\begin{tabular}{|c|c|c|c|c|}
\hline Variable & Mean & St. Dev. & Min. & Max. \\
\hline \hline CASH & 0.1496 & 0.1196 & 0.0067 & 0.3563 \\
\hline MII & 0.1013 & 0.0418 & 0.0195 & 0.1341 \\
\hline M2 & 0.1153 & 0.0429 & 0.0440 & 0.1770 \\
\hline SIZE & 8.2014 & 1.1864 & 5.4930 & 10.9464 \\
\hline MB & 1.0625 & 0.4542 & 0.3452 & 0.1332 \\
\hline CF & 0.2064 & 0.2183 & -0.1449 & 1.4625 \\
\hline NWC & 0.3624 & 0.0334 & -1.7352 & 0 \\
\hline CAPEX & 0.0837 & 0.0082 & 0.1206 \\
\hline LEV & 0.4694 & 0.2026 & 0.0798 & 0.9592 \\
\hline DIV & 0.7733 & 0.4202 & 0 & 1 \\
\hline
\end{tabular}

Source: Author's calculation.

Table 2: Pearson's Correlation Matrix

\begin{tabular}{|c|c|c|c|c|c|c|c|c|c|}
\hline & MII & M2 & SIZE & MB & CF & NWC & CAPEX & LEV & DIV \\
\hline MII & 1 & & & & & & & & \\
\hline M2 & $0.055^{*}$ & 1 & & & & & & & \\
\hline SIZE & 0.037 & 0.013 & 1 & & & & & & \\
\hline MB & $0.13^{* * *}$ & $-0.176^{\star * *}$ & $-0.061^{* * *}$ & 1 & & & & & \\
\hline $\mathrm{CF}$ & 0.037 & $0.092^{*}$ & $0.053^{*}$ & $0.109^{*}$ & 1 & & & & \\
\hline NWC & -0.013 & $-0.107^{* * *}$ & $-0.056^{*}$ & 0.068 & -0.037 & 1 & & & \\
\hline CAPEX & -0.066 & 0.016 & -0.025 & -0.061 & 0.056 & 0.072 & 1 & & \\
\hline LEV & -0.030 & -0.006 & -0.013 & -0.111 & -0.020 & 0.014 & 0.013 & 1 & \\
\hline DIV & 0.016 & 0.021 & -0.017 & 0.028 & 0.017 & -0.050 & 0.002 & 0.008 & 1 \\
\hline
\end{tabular}

$\left.{ }^{(* *}\right),\left({ }^{*}\right)$ : significant at $1 \%$, and $10 \%$. Source: Author's calculation. 
Table 3: VIF Test

\begin{tabular}{|c|c|c|c|c|c|c|c|c|c|}
\hline & MII & M2 & SIZE & MB & CF & NWC & CAPEX & LEV & DIV \\
\hline VIF & 2.87 & 2.66 & 1.31 & 1.23 & 1.11 & 1.11 & 1.08 & 1.03 & 1.01 \\
\hline
\end{tabular}

Source: Author's calculation.

Firm cash holdings range from 0.67 per cent to 35 per cent of total assets while standard deviation is 0.1196 is relatively high compared to the mean of cash holdings. The MII has small deviation of 0.0418 , indicating less variance in research period. The MII reaches maximum of 13.41 per cent and the minimum is about 1.95 per cent.

The correlations of variables are expressed by the Pearson's correlation matrix

All explanatory variables show a low correlation to each others. Some couples have significant relations at 1 per cent as those between MMI and MB; M2 and MB; SIZE and MB; and M2 and NWC. Other significant correlations (at 10 per cent) are $\mathrm{MMI}$ and M2; CF and $M 2$, SIZE, and MB; and SIZE and NWC. Low Pearson's correlation may imply no multicolinearity in the model. To confirm the non-existence of multicolinearity, Vector Inflation Factor (VIF) is employed in this case.

VIF test indicates that all variables have low VIF (smaller than 5). This confirms the hypothesis that there is no multicollinearity in the model.

The impacts of macroeconomic uncertainty on cash holdings of firms in Vietnam Stock Exchange are expressed via econometric model, which uses POLS, FEM and REM estimation methods. The results indicate that the impacts are relatively alike among three estimation methods. All directions of impacts are the same while the magnitude of impacts slightly varies.

For the selection of most suitable estimation methods, the paper employs Breusch and Pagan Lagrangian multiplier test to choose either POLS or REM. Hausman test is used for either FEM or REM estimation method.

The post-estimation selection test indicates that FEM is the most suitable. Modified Wald test also shows that there is no heteroskedasticity in the FEM model.

The results from FEM model indicate that macroeconomic uncertainty (MII and M2) has significant impacts on cash holdings of firms. Other control variables such as SIZE, MB, CF, NWC, CAPEX, LEV, and DIV affect cash holdings of firms at $1 \%, 5 \%$, and $10 \%$ level of significance.

MII has significant impacts on cash holdings of top 50 listed firms in Vietnam stock market. This confirms the findings of Demir and Ersan (2017), and Phan et al.

Table 4: Estimation Results

\begin{tabular}{|c|c|c|c|}
\hline & POLS & REM & FEM \\
\hline \hline Constant & $-0.286^{* *}$ & $-0.286^{* *}$ & $-0.728^{\star * *}$ \\
\hline MII & $0.102^{* *}$ & $0.129^{* *}$ & $0.164^{* *}$ \\
\hline M2 & $0.107^{* *}$ & $0.116^{* *}$ & $0.145^{* *}$ \\
\hline SIZE & $-0.087^{* *}$ & $-0.112^{* *}$ & $-0.147^{* *}$ \\
\hline MB & $0.165^{* * *}$ & $0.131^{* *}$ & $0.179^{* *}$ \\
\hline CF & $2.423^{* * *}$ & $2.665^{* *}$ & $2.671^{* * *}$ \\
\hline NWC & $-0.278^{* * *}$ & $-0.310^{* *}$ & $-0.322^{* * *}$ \\
\hline CAPEX & $0.056^{* *}$ & $0.090^{* *}$ & $0.101^{* *}$ \\
\hline LEV & $0.856^{* * *}$ & $1.000^{* * *}$ & $1.123^{* * *}$ \\
\hline DIV & $-0.051^{*}$ & $-0.071^{*}$ & $-0.078^{*}$ \\
\hline$R^{2}$ & 0.342 & 0.412 & 0.437 \\
\hline
\end{tabular}

$\left({ }^{* * *}\right),\left({ }^{* *}\right),\left({ }^{*}\right)$ : significant at $1 \%, 5 \%$, and $10 \%$. Source: Author's calculation. 
Table 5: Post-Estimation Tests

\begin{tabular}{|c|c|c|}
\hline \multicolumn{2}{|c|}{ Test } & Results \\
\hline \hline $\begin{array}{c}\text { Breusch and Pagan Lagrangian multiplier } \\
\text { test }\end{array}$ & REM - POLS selection & Prob $>$ chibar2 $=0.000$ \\
\hline Hausman test & FEM-REM selection & Prob $>$ chi2 $=0.0008$ \\
\hline $\begin{array}{c}\text { Modified Wald test for groupwise } \\
\text { heteroskedasticity }\end{array}$ & FEM heteroskedasticity $>$ chi2 $=0.152$ \\
\hline
\end{tabular}

Source: Author's calculation.

(2017). The result indicates that higher macroeconomic uncertainty will lead to higher cash holdings in firms. In 2008, when the economy fell into the recession, firms had to increase reserve as well as be more careful in investment to ensure the cash flow. In recent years, the Vietnamese economy has been recovered while inflation and interest rate are under control. As a result of stable economy, firms has reduced reserve for precautionary motive and utilized capital resource for firm's operation. This confirms the hypothesis that higher macroeconomic uncertainty will result higher level of cash holdings of firms. The same effect happens to money supply (M2). M2 has significantly positive impacts on cash holdings (Yang et al., 2017).

Firm size (SIZE) has negative impacts on cash holdings of listed firms in Vietnam stock market. This direction of significant impacts is similar to those of Ozkan and Ozkan (2004), and Phan et al. (2017). The result shows the diseconomies to scale in cash holdings and confirms the hypothesis that bigger firms hold less money. It can be explained that most of transactions in bigger firms via banking system and thus these firms hold less cash.

Market-booked value of firms has significant and positive impacts on cash holdings of top 50 listed firms in Vietnam Stock Market. This result is supported by Ozkan and Ozkan (2004), and Ferreira and Vilela (2004). Higher rate between market value and booked value of firms would result higher level of firm cash holdings. Firms with higher rate of MB may have higher opportunity to promote their market or products, which need internal liquidity to support the chance. Higher investment opportunity would in turn increase market value of firms, and thus confirms the research hypothesis (Ferreira and Vilela, 2004; Phan et al., 2017). Cash flow, Leverage and firm investment have positive effects on firm cash holdings and this result is in accordance to those of Anderson (1999), Ferreira and Vilela, (2004), Ozkan and Ozkan (2004), Drobetz and Grüninger (2007), Ogundipe et al. (2012), and Phan et al. (2017).
Net Working Capital and dividend significantly affect firm cash holdings. The negative sign of NWC coefficients imply that whenever NWC increases, cash in firm will reduce. This also shows that firms with low opportunity cost of liquidity will hold less cash (Phan et al., 2017). There is difference between firms with dividend in cash and firms with no dividend. Dividend in cash will reduce the amount of cash in firms or after paying dividend in cash, firms will have lower level of cash.

\section{CONCLUSION}

The increasing concerns relating to firm financial policy as well as firm cash holdings become more important to policy maker while macroeconomic indicators could be an important determinant affecting firm decision of cash holdings. Basing on literature review, the paper forms a model to identify the impacts of macroeconomic uncertainty on cash holdings of top 50 listed firms in Vietnam Stock Exchange. The dataset includes 300 observations from from top 50 listed firms in both Ho Chi Minh City Stock Exchange and Hanoi Stock Exchange from 2013-2018, and these two stock exchanges are also sources for microdata collection. Macrodata including money supply, inflation rate, exchange rate, deficit, external debt, and GNP are from the World Development Indicators 2019. The average value of natural logarithm of inflation rate, change in exchange rate, deficit to GNP, and external debt to GNP ratio is used for proxy of macroeconomic uncertainty. Firm cash holdings are measured by the ratio of cash and cash equivalent to total assets. The quantitative method is used to measure the impacts of macroeconomic uncertainty on firm cash holdings. Three estimation methods including POLS, FEM, and REM are silmutanously employed. The robust results support all hypotheses given in this paper. Macroeconomic uncertainty will increase the rate of cash holdings in firms. Money supply, an indicator of monetary polity, also has positive effects on firm decision in holding cash. Other factors that increase 
the rate of cash and cash equivalent to total assets of fims would be the ratio of maket and booked value of firm, cash flow, firm investment, and firm leverage. There are some factors that negatively affect firm cash holdings including firm size, net working capital, and firm dividend.

The empirical results reveal some implications for policy makers. Firstly, firms hold less cash in a stable economic environment. This means that when the government want to minimize the cash transaction as well as cash holdings in firms, it is necessary to hold the macroeconomic stable. Like other developing economies, there is a large amount of cash in the economy while the usage of electronic money is still limited. Besides the regulations, stability of macroeconomic conditions such as economic growth, inflation, deficit, and external debt are important factor in reducing cash holdings of firms. In addition, the monetary policy should be carefully used when considering the amount of cash holdings in firms. Increasing money supply would also directly affect cash holdings and indirectly via inflation. Secondly, policy on cash holdings of firms should pay attention to some determinants such as firm size, cash flow, net working capital, investment, leverage, as well as firm dividend policy in order to reach the targeted level of firm cash holdings. Changes of these determinants can affect cash holdings so the policy must be sufficiently adjusted.

\section{REFERENCES}

Afza, T., \& Adnan, S. M. (2007). Determinants of corporate cash holdings: A case study of Pakistan. Proceedings of Singapore Economic Review Conference (SERC).

Anderson, T. (1999). The Meaning of Deregulation. Journal of Australian Political Economy, 45, 1-9.

Bahmani-Oskooee, M., Kutan, M. A., \& Xi, D. (2013). The impact of economic and monetary uncertainty on the demand for money in emerging economies. Applied Economics, Taylor and Francis Journals, 45(23), $3278-3287$ https://doi.org/10.1080/00036846.2012.705430

Bates, T. W., Kahle, K. M., \& Stulz, R. M. (2009). Why Do U.S. Firms Hold So Much More Cash than They Used To? The Journal of Finance, 64(5), $1985-2021$. https://doi.org/10.1111/j.1540-6261.2009.01492.x

Baum, C. F., Caglayan, M., Ozkan, N., \& Talavera, O. (2006). The impact of macroeconomic uncertainty on non - financial firm's demand for liquidity. Review of Financial Economics, 15(4), $289-304$. https://doi.org/10.1016/j.rfe.2006.01.002
Chen, D., Li, S., Xiao, J. Z., \& Zou, H. (2014). The effect of government quality on corporate cash holdings. Journal of Corporate Finance, $27(\mathrm{C}), 384-400$. https://doi.org/10.1016/j.jcorpfin.2014.05.008

Demir, E., \& Ersan, O. (2017). Economic policy uncertainty and cash holdings: Evidence from BRIC countries. Emerging Markets Review, 33(C), $189-200$. https://doi.org/10.1016/i.ememar.2017.08.001

Drobetz, W., \& Grüninger, M. (2007). Corporate Cash Holdings: Evidence from Switzerland. Financial Markets and Portfolio Management, 21(3), $293-324$. https://doi.org/10.1007/s11408-007-0052-8

Ferreira, M. A., \& Vilela, A. S. (2004). Why Do Firms Hold Cash? Evidence from EMU Countries. European Financial Management, 10(2), 295 - 319. https://doi.org/10.1111/j.1354-7798.2004.00251.x

Gill, A., \& Shah, C. (2012). Determinants of Corporate Cash Holdings: Evidence from Canada. International journal of Economics and Finance, 4(1), 70-79. https://doi.org/10.5539/ijef.v4n1p70

Hemmati, H., Rezaei, F., and Anaraki, N. B. (2013). Investigating the Financial Determinants of Corporate Cash Holdings in Tehran Stock Exchange. Interdisciplinary journal of contemporary research in business, 5(6), $92-101$.

Islam, S. (2012). Manufacturing Firms' Cash Holding Determinants: Evidence from Bangladesh. International Journal of Business and Management, 7(6), 172 - 184. https://doi.org/10.5539/ijbm.v7n6p172

Ismihan, M., Metin - Ozcan, K., and Tansel, A. (2002). Macroeconomic Instability, Capital Accumulation and Growth: The Case of Turkey 1963-1999. ERC Working Papers in Economic 02/04. https://doi.org/10.2139/ssrn.441180

Kim, C., Mauer, D., and Sherman, A. (1998). The determinants of corporate liquidity: Theory and evidence. Journal of Financial and Quantitative Analysis, 33(3), 335-359. https://doi.org/10.2307/2331099

Ogundipe, S. E., Salawu, R. O., and Ogundipe, L. O. (2012). The Determinants of Corporate Cash Holdings in Nigeria: Evidence from General Method of Moments (GMM). International Journal of Economics and Management Engineering, 6(1), 152 - 158.

Ozkan, A., and Ozkan, N. (2004). Corporate cash holdings: An empirical investigation of UK companies. Journal of Banking \& Financial, 28(9), $2103-2134$ https://doi.org/10.1016/i.jbankfin.2003.08.003

Phan, H. V., Nguyen, N., Nguyen, H. T., and Hegde, S. P. (2017) Government Economic Policy Uncertainty, Corporate Cash Holdings, and the Value of Cash. Working Papers, 17-10. https://doi.org/10.2139/ssrn.3051576

World Development Indicators (2019). Washington, D,C: World Bank.

Yang, X., Han, L., Li, W., Yin, X., and Tian, L. (2017). Monetary policy, cash holding and corporate investment: Evidence from China China Economy Review, 46(C), 110-122. https://doi.org/10.1016/i.chieco.2017.09.001

Yepifanova, I. M. (2019). Improving Efficiency of Asset Management in the Context of Ensuring Competitiveness of Mechanical Engineering Enterprises in Developing Countries. Journal of Reviews on Global Economics, 8, 847-855. https://doi.org/10.6000/1929-7092.2019.08.73

Zakaria, N., Kamaludin, K., and Alkhalifa, A. (2019). Method of Payments in the Merge and Acquisitions Transaction: The Case of Saud Arabia. Journal of Reviews on Global Economics, 8, 688-694. https://doi.org/10.6000/1929-7092.2019.08.59

\section{DOI: https://doi.org/10.6000/1929-7092.2020.09.21}

(C) 2020 Van Dung Ha; Licensee Lifescience Global.

This is an open access article licensed under the terms of the Creative Commons Attribution Non-Commercial License (http://creativecommons.org/licenses/by-nc/3.0/) which permits unrestricted, non-commercial use, distribution and reproduction in any medium, provided the work is properly cited. 